\title{
MANAJEMEN MUTU PEMIMPIN DAN KEPEMIMPINAN KONTEMPORER BAGI PENINGKATAN PERGURUAN TINGGI KEAGAMAAN DI ABAD XXI
}

\author{
Stevri Indra Lumintang
}

\begin{abstract}
The objective of this research was to analize deeply and objectively the contemporary management quality of some leaders and their leadership at religiousity higher educations in Indonesia for finding a model of quality improvement the higher education. This research was based upon the naturalistic paradigm with qualitative approach, and the said methodology was a phenomenologic method, by using Ishikawa Fishbone Diagram as a technical tool to improve the quality. The datas were colleted through participant observation using interview, and document study. The data analysis and interpretation indicate that: (1) The real problem is the weak management quality; (2) The weak management quality is caused by the weak leaders and leadership. This main factor influences other factors, just as all influence one and another; (3) The root of weak management quality is caused by the weak leader and leadership. The findings lead to the recommendation to practice quality improvement, and to apply the model of quality improvement, in order for it be one of the quality religiousity higher education in this $21^{\text {st }}$ century.
\end{abstract}

Keywords: quality management, leader and leadership, contemporary, and improvement

\section{A. Pendahuluan}

Suatu bangsa yang berkualitas dapat diukur oleh kualitas sumber daya manusia bangsa tersebut. Karena itu, tidak ada cara untuk membangun suatu bangsa selain dengan cara membangun sektor pendidikan bangsa tersebut. Paradigma inilah yang dimiliki oleh the Founding Fathers bangsa Indonesia, Soekarno-Hatta dan rekan-rekannya, dengan filosofinya Build Nation, Build School (Soedijarto 2009:7). Hal itu berarti, dengan membangun sektor pendidikan, maka terbangunlah sektor ekonomi, sosial, politik, dan budaya bangsa tersebut. Dengan kata lain, mencerdaskan kehidupan bangsa adalah starting point pembangunan bangsa di segala bidang.

Tentu sekolah dan bangsa tidaklah dapat dipisahkan, bahkan terdapat hubungan yang kuat antara pendidikan (kampus) dengan pembangunan bangsa (Tilaar 2008:95). Karena itu, mutu pendidikan suatu bangsa menjadi tolok ukur mutu bangsa itu sendiri. Mutu pendidikan suatu bangsa berakar dari mutu manajemen pendidikan bangsa tersebut. Sangat disayangkan, dalam empat dekade terakhir ini, mutu pendidikan di Indonesia tidak mengalami peningkatan yang signifikan, karena dalam Kenya-taannya mutu pendidikan di Indonesia pada dekade ini berada di bawah mutu negara-negara yang dahulunya di bawah Indonesia seperti Malaysia dan Vietnam (Taniredja 2010:3-4). Hal itupun, terlihat pada mutu kesejahteraan masyarakat bangsa-bangsa tersebut. 
Rendahnya mutu pendidikan di Indonesia terungkap pada rendahnya perhatian baik rakyat maupun pemerintah terhadap sektor pendidikan. Pendidikan masih belum dianggap sebagai prioritas pembangunan bangsa (Octavianus 2005:313). Karena itu, banyak rakyat yang sulit mendapatkan akses pada pendidikan yang layak. Dengan kata lain, pendidikan masih berpihak pada rakyat yang berada di tempat-tempat yang dekat dan sangat dekat dengan pusat pemerintahan. Yang sangat kentara, ialah kecilnya alokasi anggaran untuk bidang pendidikan, hanya $20 \%$ dari APBN dan itu pun hanyalah "janji politik yang kosong" (Prayitno 2008), padahal telah tercantum dalam UUD 1945, dan kalaupun telah diimplementasikan pada satu decade terakhir ini, itu belum tepat sasaran, karena masih meliputi semua pendidikan, lagi pula hanya $20 \%$, masih sangat kecil untuk suatu negera yang berkembang. Hal ini diperparah dengan buruknya politik pendidikan di Indonesia terungkap melalui buruknya kinerja pendidikan, seperti yang nampak pada lemahnya SDMnya (Ghafur 2008:2-3).

Selain apa yang dikemukakan di atas, pemerintah terkesan cenderung "kalap" mengejar ketertinggalan, dengan proyek perubahan kurikulum (KBK dan KTSP dan Kurikulum 2013), Ujian Nasional dan BHP, namun semuanya terkesan sebagai "uji coba" sehingga pendidikan di Indonesia dijadikan "kelinci percobaan" tanpa perbaikan yang berarti, dan "tambal sulam" ini justru semakin memperbesar "kain pendidikan yang sobek". Alhasil, tidak satupun Perguruan Tinggi (PT) di Indonesia terbilang dalam 100 universitas terbaik di Asia (Tilaar 2006:77), dan sampai tahun 2017 yang lalu, Indonesia masih berada di bawah Singapura, Brunei Darussalam, Malaysia dan Thailand (Sahroji 2017). Bank Dunia pun melalui CNN menyatakan bahwa Kualitas Pendidikan Indonesia masih rendah (Fauzie 2018). Apalagi dengan Perguruan Tinggi Kegamaan Kristen di Indonesia, hanya sebagian kecil yang dapat memenuhi batas minimal Standar Nasional Pendidikan, sedangkan yang lainnya berjuang "setengah mati" untuk memenuhinya.

Salah satu faktor penyebab lemahnya mutu perguruan tinggi adalah faktor pemimpin dan kepemimpinan (Danim, 2010; Mulyasa, 2009; Indrajit, 2006). Dalam kenyataannya memang, khususnya pemimpin dan kepemimpinan perguruan tinggi keagamaan cenderung menerapkan pola manajemen tradisional. Padahal pola kontemporer telah menyebabkan banyak perguruan tinggi mencapai kemajuan, namun tidak mudah bagi perguruan tinggi keagamaan meninggalkan pola tradisional. Manajemen pola tradisional adalah berorientasi pada visi agama, dipimpin oleh senior, pemimpin berasal dari atas, berpegangan pada dogma (theologi) agama yang eksklusif, mempertahankan status quo, sehingga cenderung kaku, sinis dan tertutup terhadap perubahan, terlalu waspada, dan enggan bekerjasama dengan pihak luar (Subagja, 2010; Mu'arif, 2008; Antone, 2010; Idrus, 2009). Akibatnya banyak perguruan tinggi kegamaan tertinggal jauh, tidak memenuhi Standar Nasional Pendidikan dan banyak yang belum terakreditasi, bahkan terancaman untuk ditutup (Gaharu, 2011), dan sekarang ini, ribuan program studi teologi yang belum terakreditasi, ratusan Sekolah Tinggi Teologi yang mandek.

Bertolak dari latar belakang masalah di atas, tulisan ini bermaksud untuk menggali mutu beberapa perguruan tinggi kegamaan di Indonesia yang diselenggarakan oleh lembaga gereja dan gerejawi dengan pola kepemimpinan tradisional, dan kemudian memberikan proposal dan petunjuk mengenai pemimpin dan kepemimpinan kontemporer bagi peningkatan mutu manajemen mutu perguruan-perguruan tinggi keagamaan di Indonesia. 


\section{B. Kajian Teoretik}

Sebelum mengadakan penelitian pada beberapa perguruan tinggi teologi di Indonesia yang nota bene adalah perguruan tinggi keagaman, maka terlebih dahulu dikemukakan mengenai mutu perguruan tinggi, mutu pemimpin dan kepemimpinan, manajemen mutu pemimpin dan kepemimpinan kontemporer sebagai landasan teoretik.

\section{Mutu Perguruan Tinggi}

Perguruan tinggi yang bermutu ditentukan oleh mutu manajemen dengan manajemen mutunya. Karena itu, menurut Sallis menemukan sumber mutu adalah suatu petualangan yang penting (Sallis 2010: 29-30). Menurut ISO 8402, mutu adalah segala sesuatu yang menentukan kepuasan pelanggan dan adanya upaya perbaikan terus-menerus. Demikian juga pendapat Ishikawa: "Good quality means the best quality...that will safisfy the comsumbers's needs" (Ishikawa 1989:16). Ada empat aspek dari mutu, menurut Iskhikawa, yaitu quality, cost, deliver and service (Is-khikawa 1989:17). Abdullah menulis bahwa mutu adalah berkenaan dengan sejumlah keistimewaan produk, dan bebas dari kekurangan atau kerusakan (Abdullah 2011:5). Karena itu, kriteria mutu perguruan tinggi adalah relevance, academic atmosphere, internal management, sustainable, efficiency and produc-tivity, leadership, access and equity (dikenal RAISELE).

Total Quality Management yang disingkat TQM adalah trend manajemen di era globalisasi yang sedang diterapkan dalam pendidikan. Carr, Hard dan Trahant mengemukakan keunggulan TQM adalah meningkatkan proses dan produksi, menghemat waktu, berfokus pada pelanggan, menekankan team-work, dengan struktur organisasi yang baru (1999:15). Tilaar mengemukakan lima prinsip TQM, yakni pusat pengembangan mutu, produk yang relevan dengan kebutuhan konsumen, proses yang diarahkan kepada produk yang bermutu, kepemimpinan yang kuat komitmen dari seluruh stakeholders pendidikan tinggi (Tilaar 2009:309).

Quality Planning (perencanaan mutu) adalah langkah pertama yang ditempu, setelah melewati langkah awal, yakni Quality Awarness (kesadaran mutu). Adapun tahap-tahap perencanaan mutu adalah sebagai berikut: (1). Mengidentifikasi pelanggan; (2). Menentukan kebutuhan pelanggan; (3). Menciptakan keistimewaan produk yang sesuai dengan kebutuhan pelanggan; (4). Menciptakan proses yang mampu menghasilkan keistimewaan produk; (5). Mentransfer atau mengendalihkan proses kepada operasi (Abdullah 2011:26).

Quality Control adalah langkah kedua. Menurut Ishikawa: "to practice quality control is to develop, design, produce and service a quality product which is most economical, most useful, and always satisdatory to the customar" (1985:44). Adapun langkah-langkahnya adalah: (1). Menetapkan unit penjamin; (2). Menentukan metode pengukur; (3). Menetapkan karakteristik mutu; (4). Mencapai kesepakatan mengenai kerusakan; (5). Menyingkapkan kekurangan-kekurangan yang ada; (6). Mengamati mutu secara statistik; dan (7). Menetapkan target mutu (Ishikawa 1985:49-54).

Quality Assuranced adalah hal yang esensial dari pengendalian mutu (quality control) dan pengendalian mutu terpadu (total quality control), demikian pendapat Ishikwa (1985:398). Karena itu, Ishikawa mengartikan bahwa: "Quality assuranced is to assure quality in a product so that a customar can buy it with confidence and use it for a long 
period of time with confidence and satisfaction" (1985:75). Imple-mentasi quality assuranced di perguruan tinggi adalah untuk memenuhi tuntutan stakeholders, dan menurut Sallis, stakeholders-lah yang memperoleh kepuasan di perguruan tinggi (2010:5-11). Adapun komponen penjaminan mutu meliputi kurikulum, program studi, dosen, mahasiswa, proses, sarana dan prasarana, suasana akademik, keuangan, penelitian dan publikasi, pengabdian, tata pamong, manajemen lembaga, sistem insformasi dan kerjasama (Sumardjoko 2010:17).

Quality Improvement adalah langkah berikut dan seterusnya dari quality control and assuranced. Quality Im-provement menurut Ishikawa: "Taking positive steps to improve existing capabilities" (Ishikawa 1985:69). Untuk itu, ada tiga syarat yang harus dipenuhi, yakni: (1). Top management mendukung inovasi; (2). Menciptakan suatu atmosfir untuk berinisyatif dan berusaha menghindari kega-galan; (3). Menjadi suatu lembaga yang mampu menanggapi segera semua stimulir luar (Ishikawa 1985: 69). Ada lima cara peningkatan mutu: (1). Passive improve-ment: mengurangi pekerjaan ulang, meningkatkan bidang kerja, memotong biaya dan mengeliminasi sebab-sebab. (2). Active improvement: menghasilkan terobo-san-terobo-san, meningkatkan mutu, kapabilitas proses, kesetaraan dengan pelanggan. (3). Immediate vicinity improvement: Plan, Do, Check and Action (PDCA). (4). Priority-Based Improvement: menghilangkan masalah utama semua komponen. (5). GoalOriented Improvement: memotong biaya, menyederhanakan kerja, dan mempersingkat waktu (Ishikawa 1985: 71-72).

\section{Mutu Pemimpin dan Kepemimpinan}

Pemimpin perguruan tinggi adalah orang kunci untuk mewujudkan perguruan tinggi yang bermutu, seperti pendapat Doreche yang dikutip oleh Danim, bahwa: "I never seen a good school without a good principle" (Danim 2010: 37). Pemimpin adalah orang yang mengarahkan dan mempengaruhi aktivitas dari anggota organisasi (Stoner 1996: 11). Karena itu, pemimpin perguruan ti-nggi adalah seorang visioner (Indrajit 2006:49). Visi pemimpin perguruan tinggi harus dibatasi oleh waktu pencapaiannya (Engkoswara 2010:137), dan sesuai dengan tri dharma. Pengangkatan dan pemberhentian pemimpin adalah sesuai dengan ketentuan yang berlaku, dengan menerapkan pola "management is how to get things (goals) done with other people" (Indrajit 2006: 31) dan memperhatikan kepemimpinan kontemporer (Usman 2009:358-361).

Kualifikasi pemimpin adalah orang yang efektif memberi perintah, inspirasi, membangun kelompok kerja yang kompak, menjadi teladan, diterima oleh ba-wahan (Anzizhan 2006:40). Enkoswara menekankan aspek keteladanan seorang pemimpin (2010:95). Secara khusus, pemimpin sekolah, menurut Mulyasa adalah orang yang mampu berperan sebagai educator, manajer, administrator, supervisor, leader, innovator, dan motivator (EMASLIM) (2009:98). Sesuai dengan Nomor 60 tahun 1999, tugas pemimpin perguruan tinggi adalah "Memimpin penyelenggaraan pendidikan, penelitian dan pengabdian masyarakat, membina tenaga kependidikan, mahasiswa, tenaga administrasi universitas/institute serta hubungan dengan ling-kungannya. Karena itu, pemimpin perguruan tinggi adalah manajer dan profesional.

Seorang pemimpin profesional harus menguasai pekerjaan, mempunyai loyalitas, mempunyai integritas, mampu bekerja keras, mempunyai visi, mem-punyai kebanggaan, 
mempunyai komitmen dan mempunyai motivasi, demikian menurut Mahrip (Bupatimaju.blogspot. com). Dalam hal ini, rektor tidak hanya sebagai pemimpin melainkan juga seba-gai manajer, yaitu berdasarkan otoritas atau penugasan, menghasilkan sesuatu, menyelesaikan dan melibatkan hal-hal yang rutin, people who do things (Yusuf 2011:60-61). Rektor dibantu oleh empat pembantu rektor sesuai dengan bidang-nya masing-masing (Indrajit 2006:49). Mereka semua disebut sebagai Chief Executive Officer (CEO) (Indrajit 2006: 48). Rektor mengkoordinasi semua pembantu rektor untuk mencapai tujuan. Karena itu, sebaiknya rektor memahami hirarki kebutuhan menurut Abraham Maslow (Santrock 2007:512). Tugas yang demikian besar, tentu sepatutnya dibarengi dengan penghargaan yang besar pula, seperti yang telah diatur dalam Undang-Undang dan Peraturan Pemerintah.

\section{Manajemen Mutu Pemimpin dan Kepemimpinan Kontemporer}

Teori mutu pada era postmodern ini adalah teori kontemporer, yaitu teori yang berorientasi pada kepuasan pelanggan, keistimewaan produk, dan adanya perbaikan secara terus menerus (Ishikawa, 1989; Sallis 2010). Manajemen mutu terpadu adalah salah satu teori kontemporer, yang menekankan kriteria mutu perguruan tinggi, yaitu relevan, suasana akademik, manajemen internal, dapat bertahan, efisiensi, produktif, kepemimpinan, akses dan adil. Kriteria ini dikenal RAISELE (Carr and Hard, 1999; Tilaar, 2009). Mutu dimulai dari kesadaran mutu, dilanjutkan dengan perencanaan mutu dan pengendalian mutu (Abdullah, 2011; Ishikawa, 1985; Sallis, 2010). Pengendalian mutu diikuti penjaminan mutu (Sumardjoko, 2010) dan berlanjut pada peningkatan mutu yang berkelanjutan, karena inovasi dan tuntutan mutu adalah berkelanjutan juga (Mulyasana, 2011; Alifuddin, 2012; dan Yusuf, 2011). Untuk menerapkan manajemen mutu, diperlukan pemimpin dan kepemimpinan kontemporer (Indrajit, 2006; Drucker, 1999; Johnson, 1995), yaitu visioner, demokratis, otonom, tim, inklusif, manajerial, edukator dan holistik

Pemimpin dan kepemimpinan kontemporer berorientasi pada visi (Indrajit, 2006; Sumardjoko, 2010; Usman, 2009; Tilaar, 2009), dan memiliki kemampuan memengaruhi semua elemen dalam upaya mencapai visi (Danim, 2010; James Stoner, A.F. Freeman, R. Edward, 1996). Demokrasi karena berasal dari bawah, hasil pilihan sesama dan bekerja bersama-sama dengan bawahan (PP Nomor 60 Tahun 1999), bukan mempekerjakan atau memerintah bawahan (Indrajit, 2006). Otonom karena kemandirian pengelolaan perguruan tinggi (UU RI Nomor 20 Tahun 2003; PP Nomor 12 Tahun 2012; Adar, 2007). Kepemimpinan tim atau puncak memperlakukan karyawan sebagai mitra, berbasis teknologi, berfokus pada visi, bermitra global (Indrajit, 2006). Inklusif yang kritikal, terbuka pada perubahan dengan mempertahankan nilai-nilai identitas dan integritas agama dan bangsa (Nandika, 2007; Smith, 1999; Widdah, 2012; Sutjipto, 2012; dan Nugroho, 2010). Kecakapan manajerial dengan kemampuan membuat perencanaan strategik, pengorganisasian, pengkoordinasi, mengendalian, dan pengevaluasian (Akdon, 2009; Gitusudarmo, Mulyono, 2009; Abbas, 2009; Kaplan, 1996). Kecakapan manajerial dipadukan dengan kecakapan holistik yaitu sebagai edukator, administrator, supervisor, pemimpin, inovator, dan motivator yang disingkat dalam bahasa Inggrisnya EMASLIM (Mulyasa 2009:98; Yusuf 2011).

Pemimpin dan kepemimpinan kontemporer yang digambarkan di atas ini, bersinergi dengan manajemen mutu. Dengan kata lain, manajemen mutu dapat diaplikasikan oleh 
pemimpin dan kepemimpinan kontemporer. Dengan demikian, tujuan penelitian ini adalah untuk menemukan sebab-sebab lemahnya mutu pemimpin dan kepemimpinan yang menyebabkan lemahnya manajemen perguruan tinggi dengan menggunakan diagram sebabakibat, yang dikenal dengan Ishikawa Fishbone Diagram.

\section{Metode Penelitian}

Paradigma penelitian ini adalah fenomenologi atau naturalistik. Berdasarkan paradigma ini, penulis mengemukakan tiga asumsi: (1) mengenai kenyataan, fokus penelitian adalah suatu kenyataan yang jamak, sebagai suatu susunan yang terkait satu dengan yang lain di salah satu perguruan tinggi keagamaan; (2) mengenai peneliti dan yang diteliti, keduanya adalah saling berinteraksi dengan berpartisipasi aktif di perguruan tinggi tersebut; (3) mengenai hakikat kebenaran, penelitian naturalistik lebih cenderung kepada uraian yang lebih detail, bukan pada generalisasi. Bersesuaian dengan paradigma penelitian, maka pendekatan penelitian ini adalah kualitiatif. Karena penelitian ini adalah untuk meneliti proses sosial suatu organisasi, yakni di perguruan tinggi keagamaan tersebut, maka jenis metode penelitian adalah studi fenomenologi.

Fenomenologi adalah metode penelitian yang berusaha membangun pemahaman tentang realitas. Pemahaman tersebut dibangun dari sudut pandang para informan tentang apa yang mereka pikirkan, katakan dan lakukan secara subyektif. Karena itu teknik pengumpulan data adalah dengan wawancara kepada para informan secara mendalam dan terbuka. Para informan adalah semua unsur pimpinan Puncak Perguruan Tinggi dan dosendosen tetap. Wawancara berlang-sung baik di kantor maupun di rumah para informan. Pewawancara menulis semua jawaban informan, dan setelah itu menyalinnya dalam catatan lapangan. Setelah itu, diadakan analisis taksonomi dengan teknik Ishikawa Fishbone Diagram, yaitu menggali sebab-sebab dari masalah lemahnya pemimpin dan kepemimpinan. Langkah-langkah diagram ini adalah: (1) merumuskan masalah mutu. (2) mencari faktorfaktor penyebabnya. (3) mencari sebab-sebab yang lebih detail sampai jenuh. (4) masukan semua ke dalam tulang utama dan sekunder, tertier sampai jenuh. Setelah diadakan analisis taksonomi dengan teknik diagram tersebut, kemudian diadakanlah analisis tema.

Dalam penelitian ini, ada tiga macam teknik pengumpulan data, yaitu: (1) wawancara mendalam dan terbuka, sesuai subfokus yaitu mengenai pengangkatan pemimpin, kualifikasi pemimpin, fungsi manajerial pemimpin, kinerja pemimpin, penghargaan, dan hubungan pemimpin perguruan tinggi dengan Badan Penyelenggara Perguruan Tinggi Swasta atau disingkat BPPTS. (2) partisipasi langsung peneliti di dalam perguruan tinggi tersebut sebagai dosen dan pemimpin. (3) penelaan terhadap dokumen tertulis. Sampel adalah "purposive" sesuai dengan fokus peneltian, yaitu salah satu perguruan tinggi keagamaan di Indonesia; dengan sampel secara berurutan: para pimpinan badan penyelenggara, pimpinan perguruan tinggi, dosen dan mahasiswa; sampel berkelanjutan sesuai subfokus; dan hasil yang diperoleh setelah berulang-ulang sampai mencapai titik jenuh. Berkenaan dengan analisis data, karena peneliti telah menetapkan tempat penelitian, subfokus, dan informan, maka peneliti tidak lagi mengadakan analisis domain, melainkan langsung pada analisis taksonomi, terstruktur dan tema yaitu melakukan wawancara terfokus berdasarkan subfokus sesuai dengan model analisis Spradley. 


\section{Hasil Penelitian}

Berdasarkan penelaan terhadap dokumen tertulis berupa buku sejarah, katalogkatalog, artikel-artikel dan buku, maka persoalan utama salah satu perguruan tinggi keagamaan yang diteliti adalah bahwa perguruan tinggi tersebut didirikan dengan visi dan misi untuk menyiapkan tenaga penyebar agama. Karena itu, tidak berfokus pada pengembangan perguruan tinggi, sehingga tidak adanya juga upaya pengkaderan pemimpin secara terencana, sistematis dan berkelanjutan. Selain itu, belum pernah terjadi pemilihan rektor oleh senat akademik, kecuali pengangkatan dan penetapan badan penyelenggara berdasarkan loyalitas dan senioritas anggota dosen di perguruan tinggi tersebut. Karena itu, memang perkembangan perguruan tinggi ini sangat lambat, sekalipun sudah berusia lebih dari lima puluh tahun (Uly, 1995; Aritonang, 1999; Octavianus, 2009) Hasil penelaan dokumen ini bersesuaian dengan temuan penelitian dengan analisis taksonomi dan tema.

\section{Kekuatan Pemimpin dan Pola Kepemimpinan}

Tanpa menggunakan teknik Ishikawa Fishbone Diagram ditemukan kekuatan pemimpin dan kepemimpinan lembaga perguruan tinggi keagamaan. Para pemimpin bersedia menjadi pemimpin karena keyakinan pribadi atas pimpinan Tuhan. Berberengan dengan itu, maka para pemimpin memiliki komitmen dengan prinsip ketaatan penuh kepada pimpinan (BPPTS). Para pemimpin menjalankan tugasnya sebagai pemimpin dengan prinsip rela berkurban (tenaga, waktu dan dana pribadi). Para pemimpin menerapkan model kepemimpinan sebagai hamba yang melayani. ara pemimpin melibatkan semua orang karena prinsip persekutuan. Para pemimpin muda menghormati yang senior dan para pemimpin senior menghargai yang muda sehingga terjadi kerjasama yang sangat baik. Sekalipun tidak ada penghargaan berupa tunjangan berkenaan dengan tugas kepemimpinan, para pemimpin bertanggung jawab melaksanakan tugasnya.

\section{Kelemahan Pola Pemimpin dan Kepemimpinan Tradisional}

Dengan teknik Ishikawa Fishbone Diagram dan analisis taksonomi, ditemukan tujuh faktor yang mengambarkan mengenai lemahnya mutu pemimpin dan kepemimpinan tradisional yang diterapkan di perguruan tinggi keagamaan yang diteliti. Kedelapan faktor dengan masing-masing penyebabnya tersebut dipaparkan secara deskriptif berikut ini:

\section{a. Pola Pengangkatan Pemimpin}

Dari data hasil analisis taksonomi maka ditemukan masalah mutu pemimpin dan kepemimpinan berakar pada sejumlah sebab secara berurutan berikut ini: Pemimpin mengalami kesulitan untuk memulai kepemimpinan. Karena, pemimpin harus terlebih dahulu membangun kepercayaan (trust) bawahan. Hal ini disebabkan oleh pola pengangkatan pemimpin yang tidak demokratis oleh BPPTS. Pengangkatan pimpinan sesuai dengan sistem dan pola kepemimpinan yang diterapkan oleh BPPTS, sesuai dengan Anggaran Dasar lembaga, yang sudah menjadi tradisi yang terpelihara sejak awal. Ketujuh faktor ini adalah faktor utama lemahnya pemimpin dan kepemimpinan.

\section{b. Kualifikasi sebagai Pemimpin}


Karena pola pengangkatan, pemimpin dilihat bukan pada kemampuan manajerial melainkan pada gelar akademik yang disandang. Hal ini dipandang penting sebagai faktor prestise dan gengsi lembaga. Gelar akademik pemimpin dianggab sebagai nilai lebih di antara perguruan-perguruan tinggi teologi di Indonesia. Selain itu, pemimpin yang diangkat adalah orang yang menjadi senior dalam lembaga, tanpa mempertimbangkan kompetensi kepemimpinan dan manajemen. Senioritas dianggab loyal pada lembaga di antara sejumlah besar tenaga yang mengundurkan diri dan meninggalkan lembaga. Ketidakpuasan anggota disebabkan oleh karena ketidakpuasan atas ketentuan dan kebijakan BPPTS.

\section{c. Kaderisasi Pemimpin}

Salah satu akibat yang ditimbulkan oleh pola yang tidak demokratis, ialah lemabnya kaderisasi pemimpin. Karena pengangkatan pemimpin adalah hak prerogatif BPPTS, memperlemah dosen mempersiapkan diri untuk menjadi pemimpin. Selain itu, tidak ada dorongan dari BPPTS kepada dosen untuk siap memikul tanggung jawab besar sebagai pemimpin. Karena pemimpin pun tidak dapat menyiapkan pemimpin selanjutnya kecuali hanya menyiapkan tenaga pendidik saja. Dalam kenyataannya juga, tidak ada upaya secara terbuka dan terencana dari pihak BPPTS menyiapkan para pemimpin. Tidak terjadi kaderisasi secara terencana dan berkelanjutan.

\section{d. Fungsi Manajerial Pemimpin}

Masih berkaitan dengan kualifikasi pemimpin di atas, lemahnya mutu kepemimpinan juga disebabkan oleh karena lemahnya fungsi manajemen para pemimpin. Dari hasil penelitian ditemukan sebab-sebabnya lemahnya fungsi manajemen, yakni: Kemampuan manajerial pemimpin tidak menjadi kualifikasi pemimpin. Kompetensi para pemimpin adalah penginjil dan pengajar. Kompetensi manajerial tidak menjadi ketentuan dan tuntutan BPPTS. Keyakinan mereka yang utama adalah berkenaan dengan panggilan utama sebagai pengkhotbah dan pengajar umat. Itulah sebabnya fungsi manajerial tidak berjalan baik.

\section{e. Kinerja Pemimpin}

Lemahnya mutu kepemimpinan terlihat pada perhatian dan energi para pemimpin juga teralihkan pada tugas-tugas yang sesungguhnya bukanlah tugas utamanya, seperti mengupayakan biaya operasional dan pengembangan lembaga. Hal ini dilakukan karena keterbatasan dukungan keuangan BPPTS dan lemahnya kemampuan ekonomi mahasiswa serta sedikitnya jumlah mahasiswa yang diterima. Hal ini disebabkan oleh karena ketentuan penerimaan mahasiswa yakni keyakinan pada panggilan Tuhan untuk menjadi hamba Tuhan (pelayan-Nya). Secara mendasar, BPPTS belum berperan sebagaimana mestinya, yang tertuang dalam undang-undang dan peraturan pemerintah tentang pendidikan tinggi.

\section{f. Visi Pemimpin}

Visi adalah salah satu kekuatan yang penting seorang pemimpin, namun hasil temuan penelitian mengungkapkan bahwa para pemimpin perguruan tinggi teologi, tidak diperkenankan memiliki visi sendiri, sebaliknya dituntut untuk mengikuti visi pendiri 
lembaga. Padahal visi pendiri lembaga tersebut bukanlah visi lembaga pendidikan melainkan visi lembaga gereja dan gerejawi. Alpanya visi pemimpin lembaga pendidikan diikuti dengan alpanya rencana operasional dan rencana strategi serta rencana induk pengembangan secara tertulis.

\section{g. Penghargaan terhadap pemimpin}

Masalah pemimpin dan kepemimpinan pada perguruan tinggi teologi di Indonesia juga adalah berkenaan dengan kecilnya penghargaan berupa gaji (salary) yang diberikan oleh BPPTS. Beban tugas besar, sedangkan penghargaan kecil. Hal ini disebabkan oleh karena BPPTS menganut prinsip bahwa jabatan dan pelayanan adalah pengabdian. Pengabdian yang dituntut adalah berdasarkan pada prinsip pelayanan dalam Alkitab. Prinsip rela berkurban ini sangat banyak dipengaruhi oleh tradisi pietisme.

\section{E. Pembahasan Hasil Penelitian}

Berdasarkan data-data yang telah dipaparkan di atas, maka masalah pemimpin dan kepemimpinan adalah berkenaan dengan masalah pengangkatan, kualifikasi, fungsi manajerial, keberlanjutan, kinerja, penghargaan dan visi. Pengangatan pemimpin dengan pola yang tidak demokrasi; kualifikasi pemimpin lebih berdasarkan loyalitas, senioritas dan gelar akademik; sehingga perguruan tinggi ini mengalami krisis kader pemimpin. Yang diangkat adalah mereka yang tidak memiliki kecakapan manajerial, akibatnya kinerja pemimpin lemah. Semuanya ini berakar juga pada visi agama menjadi visi pendidikan.

Selanjutnya, dengan melakukan analisis yang lebih mendalam (analisis komponen), peneliti menemukan sebab-sebab masalah lemahnya pemimpin dan kepemimpinan adalah seperti yang terlihat pada tulang utama yang terhubung dengan kepala ikan (lemahnya pemimpin dan kepemimpinan). Akar masalah utama ini masih disebabkan sejumlah faktor yang ada dalam tulang-tulang kecil, dan masing-masing tulang kecil inipun masih juga disebabkan oleh faktor yang lebih kecil lagi, seperti yang terlihat pada diagram Ishikawa Fishbone berikut ini.

Dengan diagram Ishikawa Fishbone dan berdasarkan analisis tema, ditemukanlah tema khusus yaitu manajemen pengabdian. Semua pemimpin dan anggota perguruan tinggi tersebut berperan dengan prinsip melayani tanpa menuntut upah. Keterlibatan personalia di semua struktur organisasi adalah berdasarkan kerelaan dan ketaatan kepada pimpinan tanpa menuntut imbalan, tanpa mengenal usia dan gelar, dapat bekerja sama dengan baik, dan dapat berkoordinasi satu dengan yang lain dengan prinsip pelayanan dan pengabdian untuk Tuhan dan lembaga tempat berkarya. Manajemen pengabdian ini merupakan kekuatan untuk mewujudkan mutu manajemen di perguruan tinggi tersebut.

Dengan melebur diri dan ikut berpartisipasi di perguruan tinggi tersebut, maka ditemukanlah tema mengenai kelemahan mutu manajemen. Perguruan tinggi keagamaan berada di antara enam dikotomi, yaitu: (1) dikotomi antara implementasi Undang-Undang Yayasan dan dengan Undang-Undang Pendidikan Nasional; (2) dikotomi antara kepatuhan kepada pimpinan agama dan pimpinan negara; (3). dikotomi antara tradisi teologi yang ekslusif dan tuntutan pendidikan yang inklusif; (4). dikotomi antara manajemen Direktur Jenderal Pendidikan Tinggi (Dikti) Kementerian Pendidikan Nasional RI dengan Direktur Jenderal (Dirjen) Bimas Kristen Kementerian Agama RI. (5). Dikotomi antara visi dan misi 
agama dan perguruan tinggi sehingga mengabaikan dharma pendidikan dan penelitian. (6) dikotomi antara interdenominasional dan denominasi. Lembaga bersifat interdenominasi sangat sulit mendapatkan dukungan sponsor dari lembaga-lembaga denominasi karena persoalan kerjasama dan kemandirian masing-masing denominasi.

Tampaknya ada hubungan yang erat antara hasil penelitian ini dengan temuantemuan yang telah dikemukakan pada bagian awal tulisan ini, bahwa perguruan tinggi yang menerapkan pola pemimpin dan kepemimpinan tradisional, lebih cenderung mengalami kemandekan dari pada kemajuan, apalagi perguruan tinggi keagamaan yang lebih eksklusif (Antone, 2010). Secara khusus, terdapat keterkaitan antara hasil penelitian dengan temuan yang menyatakan bahwa pola pemimpin dan kepemimpinan di perguruan tinggi keagamaan adalah sama dengan pola tradisional (Indrajit 2006, Sallis 2010).

Pola tradisional cenderung tidak fleksibel, agak tertutup, dan dapat memberi peluang bagi praktik manipulasi pimpinan, dan bertentangan dengan pola manajemen puncak (Sallis 2010). Pola ini lebih sesuai untuk kepemimpinan lembaga gereja, bukan untuk kepemimpinan lembaga pendidikan. Pola ini juga menyebabkan tingginya tingkat intervensi pihak badan penyelengga. Dan pola ini bertentangan hakikat perguruan tinggi yang semestinya otonom dalam manajemen (UU RI Nomor 20 Tahun 2003), otonom dalam pengelolaan akademik, operasional, personalia, keuangan dan sarpras perguruan tinggi (PP Nomor 19 Tahun 2005). Pola apostolik tidak sesuai dengan manajemen kontemporer, yaitu manajemen mutu, yang menekankan demokrasi, otonomi, dan mutu pelayanan yang berfokus pada kepuasan pelanggan (Sallis, 2010; Indrajit, 2006).

Perguruan tinggi yang sedang maju di era globalisasi ini adalah perguruan tinggi yang sedang menerapkan pola kepemimpinan kontemporer (Usman 2009; Indrajit, 2006). Pemimpin dan kepemimpinan kontemporer mensyaratkan seorang dan/atau setim kepemimpinan yang dipilih berdasarkan suara demokrasi dan memimpin secara demokratis, bukan dengan memerintah apalagi memaksa. Pemimpin diberikan otonomi untuk memenejemeni perguruan tinggi secara utuh, membentuk kepemimpinan tim yang bekerja bersama-sama, dan memiliki kompetensi holistik (Mulyasa 2009). Untuk itu pula, pola kontemporer ini menuntut kemampuan manajerial, yang dapat memfungsikan unsur-unsur manajemen, mulai dari perencanaan sampai evaluasi (Yusuf 2011). Fungsi-fungsi manajemen yang demikian dibarengi dengan kemampuan menejerial pemimpin untuk memengaruhi semua untuk mewujudkan visi perguruan tinggi (Anzizhan 2006). Kalau demikian syarat pemimpin dan kepemimpinan kontemporer, maka pola apostolik, gelar akademik dan/atau senioritas semata-mata, semuanya tidak lagi relevan sebagai pola kepemimpinan abad ke-21 ini.

Semua upaya perbaikan dan peningkatan mutu yang telah dikemukakan dalam pembahasan hasil penelitian di atas, tentu dimulai dari Badan Penyelenggara. Perlu komitmen yang tinggi untuk berperan sebagai Badan Penyelenggara sehingga dapat menyelenggarakan perguruan tinggi keagamaan mestinya yaitu sesuai dengan hakikat perguruan tinggi dan sesuai dengan undang-undang tentang pendidikan tinggi dan bukan undang-undang tentang Yayasan. Selain itu, perlu merumuskan visi dan misi perguruan tinggi keagamaan sebagai lembaga pendidikan, bukan visi dan misi agama (UU RI Nomor 19 Tahun 2003; UU RI Nomor 12 Tahun 2012).

Untuk mengatasi dikotomi dan kelemahan di atas ini, Badan Penyelenggara perlu berkonsultasi dengan Dirjen Bimas Kristen (Agama) dan Direktur Pendidikan Tinggi 
(Pendidikan), dan berdialog dengan unsur pimpinan perguruan tinggi keagamaan yang diselenggarakannya. Setelah dua hal ini ditempu, barulah menerapkan manajemen mutu, seperti manajemen mutu terpadu, dan khususnya menerapkan pola pemimpin dan kepemimpinan kontemporer. Dengan cara demikian, maka perguruan tinggi keagamaan tersebut akan mencapai standar mutu nasional bahkan internasional.

\section{G. Penutup}

Dengan mengacu kepada apa yang dikemukakan di bagian pendahuluan, dan berdasarkan hasil penelitian serta pembahasannya, maka dapatlah ditarik beberapa simpulan sekaligus rekomendasi sebagai berikut: Pertama, beberapa perguruan tinggi keagamaan yang diteliti, sekalipun sudah terbilang lama, namun mengalami stagnansi bertahun-tahun oleh karena lemahnya manajemen pemimpin dan kepemimpinan, sehingga tidak mencapai standar minimal mutu nasional pendidikan.

Kedua, lemahnya mutu manajemen perguruan tinggi keagamaan yang diteliti tersebut disebabkan oleh karena lemahnya mutu pemimpin dan kepemimpinan. Lemahnya mutu pemimpin dan kepemimpinan disebabkan oleh karena lemahnya mutu manajemen Badan Penyelenggara (BPPTS) dan karena menerapkan pola manajemen tradisional yang sentralitas, eksklusif, dari bawah ke atas, terlalu waspada, dipimpin oleh yang senior, berorientasi pada aturan (teologi) dari pada tujuan.

Ketiga, lemahnya mutu manajemen badan penyelenggara disebabkan oleh karena visi dan misi agama (lembaga gereja dan gerejawi) dijadikan visi dan misi lembaga pendidikan sekalipun tidak tertulis. Alpanya visi dan misi lembaga pendidikan disebabkan oleh karena maksud semula perguruan tinggi keagamaan tersebut didirikan dan juga oleh karena diterapkannya tradisi teologi yang bersifat eksklusif selama ini.

Keempat, tidak ada cara untuk memperbaiki lemahnya manajemen selain menerapkan manajemen kontemporer dengan cara meningkatkan mutu pemimpin dan kepemimpinan, serta menerapkan model pemimpin yang visoner, demokrasi, otonomi, kepemimpinan team, inklusif yang kritikal, manajerial, dan dengan kecakapan holistik.

Kelima, untuk mengatasi lemahnya manajemen, dimulai dengan mengatasi lemahnya mutu pemimpin dan kepemimpinan dalam konteks dan tuntutan abad ke-21. Untuk itu, model pemimpin dan kepemimpinan kontemporer, adalah model yang relevan untuk manajemen mutu, yang pada gilirannya akan meningkatkan mutu perguruan tinggi sampai mencapai standar nasional dan bahkan strandar internasional.

\section{Daftar Pustaka}

Abbas, Syahrizal, Manajemen Perguruan Tinggi. Jakarta: Kencana Prenada Media Group, 2009.

Alifuddin Moh. Reformasi Pendidikan: Strategi Inovasi Peningkatan Mutu Pendidikan. Jakarta: Magna Script, 2012

Akdon, Strategic Management for Educational Management. Bandung: Penerbit Alfabeta, 2009

Anggaran Rumah Tanggah Yayasan Penyelenggara Perguruan Tinggi Swasta 
Antone S. Hope, Pendidikan Kristen Kontekstual. Jakarta: Gunung Mulia, 2010

Aritonang S. Jan, Berbagai Aliran di Dalam dan Sekitar Gereja. Jakarta: BPK Gunung Mulia, 1999.

Danim, Sudarwan, Visi Baru Manajemen Sekolah: Dari Unit Birokrasi ke Lembaga Akademik. Jakarta: PT Bumi Aksara, 2006.

Danim Sudarwan, Otonomi Manajemen Sekolah. Bandung: Penerbit Alfabet, 2010

Drucker F. Peter, Management Challenges for the $21^{\text {st }}$ Century. New York:

HarperCollins Publishers, 1999

Edison Thomas, Kalau Tidak Akreditasi Tidak Bisa Menerbitkan Ijazah. Gaharu, Edisi 82, Pebruari 2011.

H. Engkoswara dan Aan Komariah, Administrasi Pendidikan. Bandung: Penerbit Alfabeta, 2010.

Idrus Ali, Manajemen Pendidikan Global. Jakarta: Gaung Persada, 2009

Indrajit R. Eko, R. Djokopranoto, Manajemen Perguruan Tinggi Modern. Yogyakarta: Andi Offset, 2006.

Ishikawa Kaoru, What is Total Quality Control? The Japanese Way.

Translated by David J. Lu, New Jersey, Englewood Cliffs, Inc, 1985

Ishikawa Kaoru, Guide Quality Control: Asian Productivity Organization.

Tokyo: Juse Press Ltd, 1986.

Ishikawa Kaoru, Introduction to Quality Control. New York, White Plains:

Quality Resources, 1993

Johson Mike, Managing in The Next Millennium, Jakarta: Erlangga, 2001

Katalog Salah Satu Perguruan Tinggi Keagamaan di Indonesia Tahun 1996-1998, dan 2009-2012

Laporan Tahun Rektor pada Rapat Kerja Yayasan Tahun 2012

Mu'arif, Liberalisasi Pendidikan. Yogyakarta : Pinus Book Publisher, 2008

Mulyadi, Sistem Perencanaan dan Pengendalian Manajemen. Jakarta: Penerbit Salemba Empat, 2007.

Mulyasa Dedy, Pendidikan Bermutu dan Berdaya Saing. Bandung: PT Remaja Rosdakarya, 2011.

Mulyasa H. E., Menjadi Kepala Sekolah Profesional. Bandung: PT Remaja Rosdakarya, 2009.

Nandika Dodi, Pendidikan di Tengah Gelombang Perubahan. Jakarta: LP3S, 2007

Nugroho, Riant, Perencanaan Strategis in Action. Jakarta: Penerbit PT

Elex Media Komputindo, 2010.

Octavianus Petrus, Sejarah Pemikiran Misioner Institut Injil Indonesia, Batu: 2009

Peraturan Pemerintah RI Nomor 19 Tahun 2005 tentang Standar Nasional Pendidikan

Peraturan Pemerintah Republik Indonesia Nomor 60 Tahun 1999 Tentang Pendidikan Tinggi

Peraturan Pemerintah Nomor 55 Tahun 2007 tentang Pendidikan Agama dan Pendidikan Keagamaan.

Rusli Yusuf, Pendidikan dan Investasi Sosial. Bandung: Penerbit Alfabeta, 2011

Sallis Edward, Total Quality Management in Education (terj). Jogjakarta:

Penerbit IRCiSod, 2010. 
Smith Fred, Memimpin dengan Integritas. Jakarta: Immanuel, 2002

Soyomukti Nurani, Pendidikan Berperspektif Globalisasi. Yogyakarta: Ar-Ruzz Media, 2008

Subagja Soleh, Gagasan Liberalisasi Pendidikan Islam. Malang: Madani, 2010

Sumardjoko, Bambang, Membangun Budaya Pendidikan Mutu Perguruan

Tinggi: Analisis Perguruan Tinggi Swasta di Surakarta. Yogyakarta:

Pustaka Pelajar, 2010.

Sufyarma H., Kapita Selekta Manajemen Pendidikan. Bandung: Alfabeta, 2004.

Sutjipto, 10 Windu Prof. Dr. H.A.R. Tilaar, M.Sc.Ed: Pendidikan Nasional: Arah Ke

Mana? Jakarta: Kompas, 2012

Tilaar, H.A.R., Kekuasaan Dan Pendidikan: Manajemen Pendidikan Nasional

DalamDalam Pusaran Kekuasaan. Jakarta: PT Rineka Cipta, 2009

Uly Djami Radja,Sejarah Berdirinya Sekolah Tinggi Theologia “I-3”, Batu I-3, 1995

Undang-Undang Republik Indonesia Nomor 20 Tahun 2003 tentang Sistem

Pendidikan Nasional.

Undang-Undang Republik Indonesia Nomor 12 Tahun 2012 Tentang Pendidikan

Tinggi

Usman Husaini, Manajemen: Teori, Praktik, dan Riset Pendidikan. Jakarta: PT

Bumi Aksara, 2010.

Widdah El. Minnah, Asep Suryana, Kepemipinan Berbasis Nilai dan

Pengembangan Mutu Madrasah. Bandung: Penerbit Alfabeta, 2012.

BIODATA PENULIS:

Stevri Indra Lumintang, sebagai Pendiri dan Ketua Institut Theologia Indonesia, dosen tetap Sekolah Tinggi Teologi Reformed Injil Internasional (STTRII) Jakarta, dan dosen tidak tetap di beberapa Sekolah Tinggi di Malaysia, Brunei dan Indonesia. Penulis menyelesaikan Th.M (1999), D.Min (2003) dan Th.D di International Theological Seminary, LA; D.Th in Missiology (2007) dari CCS; Dr. Manajemen Pendidikan (2013) dari Universitas Negeri Jakarta. 